\title{
JESYA
}

JURNAL EKONOMI \& EKONOMI SYARIAH

Jurnal Ekonomi \& Ekonomi Syariah Vol 4 No 2, Juni 2021

E-ISSN : 2599-3410 | P-ISSN : 2614-3259

DOI : https://doi.org/10.36778/jesya.v4i2.380

\section{Analisis Potensi Penerimaan Pajak dan Retribusi Daerah dari Sektor Pariwisata kota Semarang}

\author{
Harsoyo \\ Universitas 17 Agustus 1945 (Untag) Semarang \\ Harsoyofisip17@gmail.com
}

\begin{abstract}
Abstrak Kota Semarang mempunyai potensi destinasi pariwisata yang cukup besar meliputi berbagai jenis yaitu wisata alam, budaya, sejarah/peninggalan bahkan destinasi wisata yang bernuansa modern. Obyek Wisata yang dikelola oleh Pemerintah Kota yaitu Kampung Wisata Taman Lele, Goa Kreo, Taman Margasatwa Mangkang dan Hutan Wisata Tinjomoyo. Kemajuan pariwisata di Kota Semarang ditunjukkan oleh semakin berkembangnya aspek-aspek pariwisata yang berimplikasi pada meningkatnya jumlah kunjungan, lama kunjungan dan semakin tingginya belanja para wisatawan di Kota Semarang. Akibat lebih dari kemajuan di sektor Pariwisata ini yang diharapkan adalah tingginya penyerapan tenaga kerja, meningkatnya pendapatan daerah dari sektor pariwisata serta meningkatnya kesejahteraaan masyarakat. Penelitian ini bertujuan untuk memberikan analisis dan perhitungan potensi penerimaan pajak dan retribusi daerah dari sektor pariwisata khususnya di kota Semarang pada tahun 2017. Penelitian ini difokuskan pada pendapatan daerah kota Semarang sektor pariwisata pada akhir tahun 2019. Selanjutnya akan dirumuskan suatu rekomendasi sebagai upaya peningkatan pendapatan daerah melalui sektor ini. Dan Metode yang digunakan adalah metode deskriptif dan Metode observasi serta wawancara. Fokus penelitian ini spesifik mengkaji terkait dengan sektor pariwisata yang meliputi potensi pajak hotel, potensi pajak restoran dan potensi pendapatan dari restribusi obyek wisata di Kota Semarang. Berdasarkan hasil penelitian diketahui jika potensi pajak hotel sebesar Rp 72.295.451.633,00, dan pada tahun 2017 telah pendapatan telah mencapai 99,64\% dari target potensi pajak yang ada. Potensi pendapatan dari restoran menghasilkan potensi pajak sebesar Rp 833.952.000.000,00, dengan realisasi tercapai sebesar 13,38\% dari yang ditargetkan. Obyek wisata memberikan potensi retribusi sebesar Rp. 4.189.180.250,-. Jika dibandingkan antara realisasi kinerja pendapatan retribusi tempat rekreasi dengan potensi retribusi tempat rekreasi tercapai 94,47\%. Untuk meningkatkan pendapatan daerah sektor pariwisata maka melalui sosialisasi secara berkesinambungan dan terus-menerus mengenai obyek pajak, meningkatkan pelayanan kepada wajib pajak, mengembangkan sistem reward dan punishment bagi wajib pajak yang taat pajak dan yang menunggak, mengembangkan sektor pariwisata melalui promosi maupun peningkatan kualitas pariwisata sehingga akan lebih banyak lagi wisatawan yang berkunjung.
\end{abstract}

Kata Kunci Kata kunci : pariwisata, pajak, retribusi 


\section{PENDAHULUAN}

Indonesia merupakan salahsatu negara yang memiliki potensi pariwisata cukup besar terutama melalui berbagai program pengembangan sesuai dengan ciri khas masing-masing daerah. Negara kita yang terdiri dari banyak kepulauan dengan warisan kekayaan alam yang melimpah dari Sabang sampai Merauke menjadi sumber pendapatan untuk sektor pariwisata. Kegiatan wisata tentu saja memerlukan banyak dukungan fasilitas serta layanan yang disediakan oleh masyarakat, pengusaha, pemerintah dan pemerintah daerah. Pendapatan daerah adalah salah satu komponen yang sangat strategis bagi pemerintah daerah dalam mewujudkan kemampuan daerah mengelola sumberdaya sebagai wujud pelaksanaan otonomi daerah. Pendapatan Asli Daerah (PAD) merupakan salah satu komponen yang sangat diperhatikan untuk menentukan tingkat kemandirian daerah dalam rangka otonomi daerah (Wahjudi, 2014). Penerimaan pemerintah digunakan untuk membiayai pengeluaran pemerintah. Penerimaan pemerintah dibagi menjadi 2 (dua) yaitu penerimaan dari pendapatan pajak dan pendapatan bukan pajak. Penerimaan Negara Bukan pajak yang selanjutnya disingkat PNBP adalah pungutan yang dibayar oleh orang pribadi atau badan dengan memperoleh manfaat langsung maupun tidak langsung atas layanan atau pemanfaatan sumber daya dan hak yang diperoleh negara, berdasarkan peraturan perundang-undangan,yang menjadi penerimaan pemerintah pusat di luar penerimaan perpajakan dan hibah dan dikelola dalam mekanisme anggaran pendapatan dan belanja Negara (UU Nomor 9 Tahun 2018). Perimbangan keuangan antara Pemerintah dan Pemerintahan Daerah yang tertuang dalam UU No. 33 Tahun 2004 secara eksplisit tersirat dalam pasal 6 ayat 1 dan 2 menjelaskan bahwa sumber-sumber dari PAD meliputi 1. Pajak daerah, merupakan pendapatan yang diperoleh pemerintah daerah yang merupakan bentuk iuran wajib yang dikenakan kepada perorangan maupun lembaga seimbang dipergunakan untuk pembiayaan penyelenggara pembangunan daerah. 2 . Retribusi daerah adalah bentuk kompensasi pembayaran yang dilakukan oleh masyarakat kepada pemerintah daerah sebagai bentuk kompensasi atas pelayanan yang diterima secara langsung atau atas perizinan yang diperolenya.3.Hasil pemanfaatan potensi kekayaan daerah yang dipisahkan. 4. Pendapatan daerah lainnya yang secara hukum sah atau tidak melanggar peraturan perundang-undangan.Sesuai dengan amanat UU No. 28 Tahun 2009, jenis-jenis pajak daerah antara lain pajak penerangan jalan, pajak mineral bukan logam dan batuan, pajak parkir, pajak air tanah pajak hotel, pajak restoran, pajak hiburan, pajak bumi dan bangunan pedesaan dan perkotaan, pajak reklame, pajak sarang burung wallet, serta bea perolehan ha atas tanah dan bangunan. Pajak daerah dan retribusi daerah adalah salah satu sumber pendapatan daerah untuk membiayai pelaksanaan pemerintah daerah. Selain itu, dalam meningkatkan pelayanan kepada masyarakat dan kemandirian daerah perlu dilakukan perluasan objek pajak daerah dan retribusi daerah dan pemberian diskresi dalam penetapan tarif. Kebijakan pajak daerah dan retribusi daerah ini berdasarkan prinsip demokrasi, pemerataan dan keadilan, peran serta masyarakat dan akuntabilitas dengan memperhatikan potensi daerah. Penelitian ini bertujuan untuk memberikan analisis dan perhitungan potensi penerimaan pajak dan retribusi daerah dari sektor pariwisata khususnya di kota Semarang pada tahun 2019. Selanjutnya akan dirumuskan suatu rekomendasi sebagai upaya peningkatan pendapatan daerah melalui sektor ini. Berdasarkan latar belakang masalah tersebut, maka perumusan masalah penelitian ini adalah 1) apakah potensi penerimaan pajak dan retrubusi daerah dari sektor pariwisata memberikan kontribusi pada Pendapatan Asli Daerah (PAD) Kota Semarang ? dan 2). bagaimana strategipeningkatan pendapatan daerah sektor pariwisata di Kota Semarang?

Batasan masalah dalam penelitian ini khusus menekankan pada penerimaan pajak dan retribusi dari sektor pariwisata yaitu pajak hotel, pajak restoran dan retribusi tempat wisata di Kota Semarang, sedangkan ruang lingkup penelitian ini meliputi: 1). mengumpulkan data dan informasi terkait potensi pendapatan daerah dari sektor pariwisata. 2). melakukan analisis mengenai potensi, permasalahan, peluang dan tantangan dalam dalam peningkatan pendapatan daerah dari sektor pariwisata di Kota Semarang. 3). 
melakukan penghitungan potensi pajak dan retribusi daerah sektor pariwisata dan 4). merumuskan rekomendasi dalam rangka peningkatan pendapatan daerah dari sektor pariwisata.

Maksud Penelitian/Kajian Penerimaan Pendapatan Daerah Melalui Sektor Pariwisata Kota Semarang untuk mengetahui potensi pendapatan daerah pada sektor pariwisata sebagai bahan pertimbangan dalam penetapan target pendapatan daerah di Kota Semarang. Sedangkan tujuan penelitian memberikan gambaran penerimaan pajak dan retribusi daerah dari sektor pariwisata, menghasilkan penghitungan potensi pajak dan retribusi daerah sektor pariwisata, memberikan gambaran mengenai potensi, permasalahan, peluang dan tantangan dalam peningkatan pendapatan daerah dari sektor pariwisata di Kota Semarang dan merumuskan rekomendasi dalam rangka peningkatan pendapatan daerah dari sektor pariwisata

Dikaji dari manfaat penilitian antara lain secara teoritas untuk pengembangan ilmu pengetahuan khususnya pengembangan kebijakan dn strategi pningkatan pendapatan daerah disektor pariwisata dan sector lainnya dan manfaat untuk pemangku kepentingan sebagai bahan masukan dalam pengambilan kebijakan dan langkah-langkah strategis dalam pengglian potensi daerah sebgai upaya peningkatan pendapatan daerah.

\section{LANDASAN TEORI \\ 1. Pariwisata}

Menurut Hunzieker dan Krapf dalam Octavia (2015:30) pariwisata dapat didefinisikan sebagai keseluruhan jaringan dan gejala-gejala yang berkaitan dengan tinggalnya orang asing disuatu tempat, dengan syarat bahwa mereka tidak tinggal di situ untuk melakukan suatu pekerjaan yang penting yang memberikan keuntungan yang bersifat permanen maupun sementara". (Pariwisata merupakan potensi yang dimilki oleh daerah yang diharapkan dapat memberikan kontribusi dalam peningkatan pendapatan daerah, oleh karena itu obyek wisata yang ada didaerah diharapkan dapat mendorong perekonomian daerah yang pada akhirnya berdampak pada peningkatan pendapatan daerah. Propinsi Jawa Tengah terdiri dari 6 (enam) Kota dan 29 (dua puluh sembilan) Kabupaten, masing-masing kabupaten/kota di Provins Jawa Tengah memilikipotensi daya tarik obyek wisata bagi wisatawan lokal maupun asing (Kurniawan, 2017. Pariwisata berdasarkan UU No. 10 Tahun 2009 merupakan berbagai macam kegiatan wisata yang didukung berbagai fasilitas, dan layanan yang disediakan oleh masyarakat, pengusaha, dan Pemerintah Daerah [6], dengan beberapa jenis pariwisata antara lain.1.Pariwisata perjalanan (Pleasure Tourism).Tujuan wisata untuk menikmati perjalanan dalam masa liburan, wisata ini dilakukan bertujuan untuk menikmati suasana keindahan alam sehingga dapat meningkatkan kebugaran baik jasmani maupun rohani.2.Pariwisata rekreasi (Recreation Tourism). Pariwisata untuk menikmati perjalanan dilakukan untuk pemanfaatan hari libur untuk istirahat, menyegarkan keletihan, dan memulihkan kesegaran jasmani \& rohani.3. Pariwisata kebudayaan, Pariwisata untuk kebudayaan ditandai dengan serangkaian motivasi yang berisi tentang keinginan belajar di pusat riset, mempelajari adat-istiadat, mengikuti festival seni musik, mengunjungi monumen bersejarah, dan mengunjungi peninggalan purbakala.4.Pariwisata olahraga (Sports Tourism), menikmati event-event olahraga baik tingkat nasional maupun internasional dan wisata petualangan sebagai bentuk melatih fisik atau olah raga seperti panjat tebing, mendaki gunung, berkuda, berburu, rafting, dan memancing.5.Pariwisata urusan usaha dagang (Business Tourism).6.Pariwisata untuk urusan usaha dagang biasanya dilakukan para pengusaha atau industrialis seperti mencakup kunjungan ke pameran dan instalasi teknis.7.Pariwisata berkonvensi (Convention Tourism).Pariwisata untuk berkonvensi yang berhubungan dengan konferensi, simposium, sidang, dan seminar internasional.

\section{Dampak Pariwisata}

Pembangunan dan pengembangan potensi pariwisata merupakan salah satu potensi dalam penggalian sumber-sumber pendapatan baik pendapatan daerah maupun pendapatan negara. Pembangunan pariwisata 
unggulan diharapkan dapat meningkatkan devisa serta dapat memberikan kontribusi pendapatan kepada pelaku-pelaku kegiatan pariwisata seperti pemandu wisata, pedagang, kerajinan UMKM dan lain-lain. Kunjungan wisatawan mancanegara memberikan sumbangan devisa negara yang cukup besar untuk negara terutama wisatawan mancanegara. Sedangkan wisatawan domestik adalah sumber PAD yang potensial pada era otonomi daerah yang terus dikembangkan karena peluang yang cukup besar. Pengeluaran dari wisatawan secara langsung maupun tidak langsung adalah sumber pendapatan dari beberapa organisasi, perusahaa, maupun masyarakat perorangan pelaku usaha di sector pariwisata. Selanjutnya jumlah wisatawan yang banyak adalah pasar bagi produk lokal. Masyarakat sekitar juga mendapatkan penghasilan apabila mereka bekerja dan memperoleh upah dari pekerjaan tersebut. Pekerjaan di sektor pariwisata antara lain : Pelaku usaha bidang perhotelan maupun restoran, biro perjalanan, pedagang, penyedia layanan transportasi maupun jasa-jasa lainnya (Saputro, 2015).

Pariwisata mempunyai dampak positif bagi masyarakat daerah. Manfaat pariwisata bagi masyarakat daerah adalah pariwisata membuat adanya kontak antara orang-orang dari bagian dunia yang paling jauh, dengan berbagai bahasa, paham politik, ras, kepercayaan, dan tingkat perekonomian. Pariwisata juga memberikan pengenalan kebudayaan, dan menciptakan peluang kerja sehingga mengurangi jumlah pengangguran. Maanfaat lainnya adalah menyumbang devisa, karena wisatawan asing membelanjakan dengan mata uang dari negara masing-masing sehingga memberikan keuntungan bagi pemerintah pada khususnya dan masyarakat pada umumnya (Rizal Abu,2016).

\section{Letak Geografis Kota Semarang}

Letak geografis Kota Semarang terletak pada garis 06o50'20, 69 LS dan 110o18'56,1 BT yang terdiri dari $373,7 \mathrm{~km} 2$ dan mempunyai wilayah laut \pm 18.000 ha. Kota Semarang dibatasi oleh :

Sebelah barat berbatasan dengan kabupaten Kendal, Sebelah timur berbatasan dengan kabupaten Demak. Sebelah selatan berbatasan dengan kab. Semarang.Sebelah utara berbatasan dengan laut Jawa sepanjang garis pantai $\pm 13.6 \mathrm{~km}$ dan garis sempadan pantai $25 \mathrm{~km}$.

Secara geografis dan sosialogis Kota Semarang mempunyai daya tarik pariwisata dengan keunikan dan karakter tersendiri mulai dari perbukitan hingga daerah pantai sehingga mempunyai potensi alam yang baik jika dikelola dan dikembangkan secara optimal (Mardiyani Yuyun, 2015)

Wilayah Kota Semarang berdasarkan morfologinya di bagi menjadi dua (2) karakteristik wilayah yaitu wilayah dataran tinggi atau wilayah atas dan wilayah dataran rendah atau wilayah bawah. Kota Semarang bagian bawah mempunyai struktur geologi berupa batuan endapan (alluvium), yang berasal dari endapan sungai yang mengandung pasir dan lempung, sedangkan Kota Semarang Atas mempunyai struktur geologi berupa batuan beku. Kota Semarang terbagi atas 16 wilayah Kecamatan dan 177 Kelurahan. Berdasarkan data Badan Pusat Statistik (BPS) Kota Semarang tahun 2016 terdapat 2 sektor yang sumbangannya cukup besar dalam Produk Domestik Regional Bruto (PDRB) atas dasar harga berlaku, antara lain : sektor perdagangan, sektor industri pengolahan, dan restoran. Sumbangan dari sektor perdagangan, hotel dan restoran sampai tahun 2013 cenderung naik yakni dari 28,01\% pada 2012 menjadi 28,43\% pada tahun 2013 dengan laju pertumbuhan sebesar $10,03 \%$. Selanjutnya, untuk sumbangan dari sektor industri pengolahan mengalami kenaikan pada tahun 2013 sebesar 24,63 jika dibandingkan dengan tahun 2012 sebesar 24,36\% dengan laju pertumbuhan sebesar 13,46\%. Kota Semarang pada jaman dahulu sebagai kota perdagangan dan kota transit sehingga Kota Semarang mempunyai warisan budaya dan sejarah yang kaya. Budaya masyarakat Kota Semarang terdiri berbagai macam etnis mulai dari Cina, Arab, Jawa, dan Belanda, serta agama yang bervariasi ditandai dengan bangunan-bangunan bersejarah. Bangunan tersebut menjadi salah satu daya tarik wisata Kota Semarang yang terkenal. Kota Semarang mempunyai 64 obyek wisata, 11 wisata alam, 24 wisata budaya, dan 29 wisata buatan ( Setya, 2017) . 


\section{Obyek Wisata yang Dikelola Pemerintah Kota Semarang}

Obyek wisata adalah penggerak utama sektor kepariwisataan yang membutuhkan kerjasama seluruh pemangku kepentingan antara lain: pemerintah dan masyarakat, kerjasama langsung dari kalangan usaha dan dari pihak swasta. Selain itu obyek wisata adalah mata rantai yang paling penting dalam suatu kegiatan wisata, karena faktor utama yang membuat wisatawan mengunjungi suatu daerah wisata adalah potensi yang dimiliki obyek wisata tersebut (Devy dan Soemanto, 2017).

Menurut Undang-undang Kepariwisataan No. 9 Tahun 1990 obyek wisata merupakan segala sesuatu yang menjadi sasaran wisata. Obyek wisata dibagi menjadi 2 (dua) sebagai berikut : Obyek wisata ciptaan Tuhan Yang Maha Esa yaitu flora dan fauna, serta keadaan alam. Obyek wisata hasil karya manusia yaitu museum, peninggalan purbakala, peninggalan sejarah, seni budaya, wisata agro, wisata tirta, wisata buru, wisata petualangan alam, taman rekreasi, dan tempat liburan

Pengembangan kearifan wisata lokal Kota Semarang menjadi paket wisata menggunakan sistem klaster. 1.Klaster yang akan dikembangkan di Kota Semarang terdiri dari empat (4) klaster antara lain ( Kadarwati , 2008) :Klaster Seni Budaya, Kluster Seni Budaya berfokus pada pengembangan dan pemberdayaan seni budaya masyarakat. Kluster ini berada di Pusat Kota Semarang. Seni budaya yang akan dikembangkan yakni Tari Gambang Semarang, dan melestarikan pertunjukkan khas Kota Semarang seperti Ketoprak, Wayang Kulit, Pementasan seni teater dan Wayang Orang. Tujuan kluster seni budaya ini sebagai media atau sarana dalam mengembangkan kesenian baik lisan maupun gerak.2. Klaster Wisata Religi, berpusat di daerah Kecamatan Gayamsari dan Semarang Barat. Daerah ini mempunyai tempat unggulan antara lain : Masjid Agung Jawa Tengah dan Sam poo kong. Masjid Agung Jawa Tengah ini berfungsi sebagai tempat ibadah, dan mempunyai nilai sejarah khususnya keislaman yang sangat kental. Selain itu, Sam poo kong ini dijadikan sebagai destinasi wisata religi karena kawasan ini mempunyai nilai sejarah mengenai perkembangan peradaban pada masa itu. 3.Klaster Wisata Sejarah, berpusat di daerah Pindrikan Kidul (Kawasan Kota Lama). Wisata sejarah yang terletak di kawasan ini yaitu Lawang sewu, kota lama, tugu muda, serta museum mandala bhakti. Pengemasan wisata sejarah ini menggunakan model wisata field trip. Wisata field trip ini wisatawan yang berkunjung di bawa mengelilingi klaster wisata sejarah dipandu seorang tour guide. Tour guide ini berfungsi memandu para wisatawan merasakan atmosfir sejarah perjuangan yang ada di tempat wisata tersebut.4.Klaster Oleh-oleh khas lokal, Oleh-oleh khas lokal Kota Semarang mempunyai beraneka ragam makanan khas antara lain : lumpia, tahu bakso, wingko babat, dan bandeng presto. Selain makanan khas, juga mempunyai kerajinan batik yang bisa memikat para wisatawan domestik hingga mancanegara. Motif batik Semarang ini mampu menggambarkan keindahan yang dimiliki kota ini.

\section{Faktor yang mempengaruhi Penerimaan Daerah dari Sektor Pariwisata}

Sektor pariwisata berupa penginapan atau hotel, usaha wisata (obyek wisata, souvenir, hiburan), usaha perjalanan wisata (travel agent atau pemandu wisata), dan restoran atau jasa boga memberikan sumbangan atau kontribusi penerimaan pendapatan Kota Semrang baik dalam bentuk pajak daerah, retribusi, pendapatan Badan Usaha Milik Daerah (BUMD). Selanjutnya, beberapa faktor yang mempengaruhi penerimaan daerah Kota Semarang dari sektor pariwisata ( Sutisno, 2013; Denny, 2013) : 1. Potensi obyek wisata, Jumlah potensi obyek wisata yang dimiliki oleh Kota Semarang menjadi salah satu tujuan wisata. Jenis obyek wisata yang dimiliki oleh Kota Semarang antara lain wisata alam dan budaya. Oleh karena itu, dengan pengembangan dan peningkatan kualitas masing-masing obyek wisata yang ada diharapkan dapat meningkatkan penerimaan pendapatan daerah.2.Potensi wisatawan Jumlah wisatawan yang berkunjung ke obyek-obyek wisata di Kota Semarang memberikan dampak positip bagi pendapatan daerah maupun masyarakat setempat, semakin banyak jumlah wisatawan maka akan semakin besar peredaran uang yang dibelanjakan baik untuk kebutuhan penginapan, transportasi, kebutuhan makan maupun kebutuhan belanja 
lainnya di obyek wisata.3.Jumlah hunian hotel, Jumlah hunian hotel adalah suatu keadaan sampai sejauh mana jumlah kamar terjual, jika dibandingkan dengan seluruh jumlah kamar yang mampu dijual. Hunian kamar hotel yang memadai membuat para wisatawan tidak segan untuk berkunjung ke suatu daerah, apalagi hotel tersebut nyaman untuk disinggahi sehingga wisatawan aman dan betah untuk tinggal lebih lama di daerah tujuan wisata tersebut.4. Pendapatan perkapita, dengan pendapatan perkapita dapat mengetahu mengetahui kondisi ekonomi suatu daerah atau wilayah. Pendapatan perkapita yang tinggi mendorong naiknya tingkat konsumsi perkapita yang kemudian dapat menimbulkan insentif bagi diubahnya struktur produksi (saat pendapatan meningkat, permintaan akan barang manufaktur dan jasa juga akan meningkat lebih cepat dibandingkan dengan permintaan akan produk pertanian). Oleh karena itu, sektor pariwisata adalah salah satu sektor yang mendapatkan prioritas utama untuk memperbaiki struktur ekonomi daerah, dan dapat meningkatkan kemandirian serta dapat memberikan kontribusi yang besar terhadap PAD (Amalia dan E. Purwaningsih, 2016).

\section{METODOLOGI PENELITIAN}

Penelitian ini difokuskan pada pendapatan daerah kota Semarang sektor pariwisata pada akhir tahun 2019. Dan Metode yang digunakan adalah metode deskriptif yang bertujuan agar diperoleh gambaran bidang usaha pariwisata yang memiliki potensi terhadap pendapatan daerah, sedangkan analisa kuantitatif dilakukan bertujuan untuk mengetahui sejauh mana bidang-bidang dalam pariwisata memiliki nilai di dalam pendapatan daerah. Beberapa bidang yang mendapat perhatian antara lain : pajak hotel, pajak restoran, dan retribusi tempat rekreasi.

Dan Metode observasi dan wawancara. Observasi yaitu suatu cara pengamatan langsung dan disertai pencatatan/ pendataan hasil dari setiap kejadian yang berkaitan dengan penelitian. Wawancara yaitu suatu cara untuk memperoleh data dengan melakukan sebuah wawancara secara langsung kepada petugas di obyek wisata, dan pelaku usaha hotel dan restoran yang berkaitan dengan hal yang diteliti.

Metode analisa kuantitatif dilakukan dengan mengembangkan beberapa persamaan sebagai berikut.

1. Analisis Pajak Hotel

$$
\begin{aligned}
& \mathrm{PH}=\mathrm{Jhtl} \times \mathrm{Rth} \times \mathrm{RJk} \times \mathrm{Jh} \\
& \mathrm{NPPH}=\mathrm{PH} \times \mathrm{Tp}
\end{aligned}
$$

dimana,

$$
\begin{aligned}
& \text { PH = Pendapatan Hotel (Rupiah) } \\
& \text { NPPH = Nilai Potensi Pajak Hotel (Rupiah) } \\
& \text { Jhtl = Jumlah Hotel (Unit) } \\
& \text { Rth = Rata-Rata Pengeluaran Tamu (Rupiah/Unit) } \\
& \text { RJk = Rata-rata Jumlah Kamar Terhuni (Unit/Hari) } \\
& \text { Jh = Jumlah Hari (hari) } \\
& \text { Tp = Tarif Pajak (\%)d }
\end{aligned}
$$

Analisis Pajak Restoran

$$
\begin{aligned}
& \text { PR }=(J R \times R t \times R p t \times J h) \\
& \text { NPPR }=\text { PR } \times \text { Tp }
\end{aligned}
$$

dimana, 
$\mathrm{PR}=$ Pendapatan Restoran (Rupiah)

NPPR = Nilai Potensi Pajak Restoran (Rupiah)

$\mathrm{JR}=$ Jumlah Restoran (Unit)

$\mathrm{Rt}=$ Rata-rata tamu yang datang (Orang/hari)

$\mathrm{Tp}=$ Tarif Pajak $(\%)$

$\mathrm{Rpt}=$ Rata-rata pembayaran per tamu (Rupiah/orang)

$\mathrm{Jh}=$ Jumlah hari (hari)

\section{Retribusi Tempat Rekreasi}

Perhitungan retribusi tempat rekreasi berdasarkan pada semua fasiltas yang dimiliki di lokasi tersebut. Dalam satu obyek rekreasi dihitung dengan menjumlahkan nilai potensi retribusi untuk setiap jenis jasa pelayanan fasilitas di dalam tempat rekreasi. Potensi retribusi tempat rekreasi dihitung pada masing obyek rekreasi dengan memperhatikan fasilitas yang ada. Penghitungan potensi retribusi tempat rekreasi dalam 1(satu) obyek wisata dihitung dengan menjumlahkan nilai potensi retribusi untuk setiap jenis jasa pelayanan dan fasilitas di dalam tempat rekreasi. Beberapa pengelompokan potensi retribusi diantaranya adalah: sewa lahan, tiket tanda masuk, parkir, tiket aneka jenis permainan, dan tiket hiburan.

Persamaan umum yang digunakan adalah :

$$
\text { NPRTR }=\text { JW } x \text { Tr }
$$

Dimana :

NPRTR $=$ Nilai Potensi Retribusi Tempat Rekreasi

$\operatorname{Tr} \quad=$ Tarif retribusi

$\mathrm{JW} \quad=$ Jumlah dalam satu tahun (dihitung berdasarkan wisatawan yang masuk/ membeli tiket masuk, kendaraan yang diparkir, pembeli tiket aneka jenis permainan, dan pembeli tiket hiburan)

\section{HASIL PENELITIAN}

\section{Analisis Potensi Pajak Hotel}

Berdasarkan Peraturan Daerah Kota Semarang Nomor 3 Tahun 2011 Tentang Pajak Hotel, bahwa hotel adalah fasilitas penyedia jasa penginapan/peristirahatan termasuk jasa terkait lainnya dengan dipungut bayaran, yang mencakup juga motel, losmen, gubuk pariwisata, wisma pariwisata, pesanggrahan, rumah penginapan dan sejenisnya, serta rumah kos dengan jumlah kamar lebih dari 10(sepuluh) pengunjung. Melalui observasi dan wawancara, maka dapat diketahui bahwa tingkat hunian hotel untuk hotel Bintang 1 sebesar 47,94\%, Bintang 2 sebesar 51,25\%, dan Bintang 3 sebesar 56,83\%. Untuk Hotel Bintang 4 dan Hotel Bintang 5 diasumsikan sama dengan Hotel Bintang 3 yaitu sebesar 56,83\%, sedangkan tingkat hunian Hotel Non Bintang diasumsikan sama dengan Hotel Bintang 1 yaitu sebesar 47,94\%. Rata-rata tarif hotel di Kota Semarang untuk Hotel Bintang 1 sebesar Rp220.000, Hotel Bintang 2 sebesar Rp 250.000, Hotel Bintang 3 sebesar Rp 370.000, Hotel Bintang 4 sebesar Rp 630.000, dan Hotel Bintang 5 sebesar Rp 840.000 .

Hasil perhitungan potensi pendapatan pajak hotel di Kota Semarang dapat dibaca pada Tabel 1 berikut ini, dengan asumsi jumlah hari 365 dan indeks tarif pajak sebesar 0,10.

Tabel 1. Analisis potensi penerimaan pajak hotel

\begin{tabular}{|c|c|c|c|c|}
\hline $\begin{array}{c}\text { Kategori } \\
\text { hotel }\end{array}$ & $\begin{array}{c}\text { Penghuni } \\
\text { Kamar }\end{array}$ & $\begin{array}{c}\text { Biaya } \\
\text { rata-rata }\end{array}$ & $\begin{array}{c}\text { Persentase } \\
\text { hunian }\end{array}$ & Potensi pajak \\
\hline
\end{tabular}


DOI : https://doi.org/10.36778/jesya.v4i2.380

\begin{tabular}{|l|r|r|r|r|}
\hline Bintang 1 & 505 & 220.000 & 0,4794 & 1.944 .038 .910 \\
\hline Bintang 2 & 1410 & 250.000 & 0,5125 & 6.593 .953 .125 \\
\hline Bintang 3 & 1749 & 370.000 & 0,5683 & 13.423 .385 .234 \\
\hline Bintang 4 & 2058 & 630.000 & 0,5683 & 26.894 .064 .393 \\
\hline Bintang 5 & 727 & 840.000 & 0,5683 & 12.667 .304 .706 \\
\hline $\begin{array}{l}\text { Non } \\
\text { Bintang }\end{array}$ & 3158 & 175.000 & 0,4794 & 10.772 .705 .265 \\
\hline Total & & & & 72.295 .451 .633 \\
\hline
\end{tabular}

Jika dibandingkan antara realisasi kinerja pendapatan pajak hotel dengan potensi pajak hotel, dapat diketahui bahwa realisasi Pendapatan Pajak Hotel tahun 2017 telah mendekati potensi pajak, telah mencapai 99,64\% dari potensi pajak yang ada, sesuai data pada Tabel 2.

Tabel 2. Realisasi pendapatan pajak hotel

\begin{tabular}{|c|c|c|c|c|c|}
\hline Realisasi 2016 & Target 2017 & Realisasi 2017 & $\begin{array}{c}\text { \% } \\
\text { capaian } \\
\text { target }\end{array}$ & $\begin{array}{c}\text { Potensi } \\
\text { pajak/retribusi }\end{array}$ & $\begin{array}{c}\text { \% Realisasi } \\
\text { terhadap } \\
\text { potensi }\end{array}$ \\
\hline 66.374 .406 .216 & 69.500 .000 .000 & 72.041 .787 .841 & 103,66 & 72.304 .641 .968 & 99,64 \\
\hline
\end{tabular}

\section{Analisis Potensi Pajak Restoran}

Berdasarkan Peraturan Daerah Kota Semarang Nomor 4 Tahun 2011 Tentang Pajak Restoran, bahwa restoran adalah fasilitas penyedia makanan dan/atau minuman dengan dipungut bayaran, yang mencakup juga rumah makan, kafetaria, kantin, warung, kolam pancing, pedagang kaki lima bar, dan sejenisnya termasuk jasa boga dan katering. Pajak Restoran adalah pajak atas pelayanan yang disediakan oleh restoran. Tarif Pajak ditetapkan sebesar 10\%. Besarnya pajak terutang dihitung dengan cara mengalikan tarif pajak dengan dasar pengenaan pajak adalah jumlah pembayaran yang diterima atau yang seharusnya diterima restoran. Mengacu pada Buku Semarang Dalam Angka 2018, jumlah restoran di Kota Semarang sebanyak 4.352 unit yang tersebar di kecamatan Mijen, Gunungpati, Banyumanik, Gajahmungkur, Semarang Selatan, Candisari, Tembalang, Pedurungan, Genuk, Gayamsari, Semarang Utara dan Semarang Timur. Jmlah terbanyak di Kecamatan Semarang selatan (1.348 unit), dan paling sedikit di Kecamatan Tugu (52 unit). Berdasarkan hasil survey, rata-rata pengunjung restoran adalah150 orang. Jika diasumsi pembelian ratarata per hari sebesar Rp 35.000 per orang maka dapat dihitung potensi pajak restoran di Kota Semarang mencapai sebesar Rp 833.952.000.000,-. Jika dibandingkan antara realisasi kinerja pendapatan pajak restoran dengan potensi pajak restoran, dapat diketahui bahwa realisasi pendapatan pajak restoran masih jauh dari potensi pajak, baru mencapai sebesar 13,38\%, sesuai dengan Tabel 3.

Tabel 3. Realisasi pendapatan pajak restoran

\begin{tabular}{|c|c|c|c|c|c|}
\hline Realisasi 2016 & Target 2017 & Realisasi 2017 & $\begin{array}{c}\text { \% capaian } \\
\text { target }\end{array}$ & $\begin{array}{c}\text { Potensi } \\
\text { pajak/retribusi }\end{array}$ & $\begin{array}{c}\text { \% Realisasi } \\
\text { terhadap } \\
\text { potensi }\end{array}$ \\
\hline 91.789 .276 .983 & 107.500 .000 .000 & 111.617 .284 .979 & 103,83 & 833.952 .000 .000 & 13,38 \\
\hline
\end{tabular}

\section{Analisis Potensi Retribusi Tempat Rekreasi}

Retribusi Tempat Rekreasi dipungut Retribusi atas jenis pelayanan yang diterima serta dan fasilitas umum yang dimanfaatkan di tempat rekreasi. Obyek Retribusi adalah jasa Pelayanan dan Penggunaan fasilitas yang disediakan didalam Tempat Rekreasi. Jasa pelayanan dan penggunaan fasilitas meliputi 
4(empat) lokasi, yaitu penggunaan fasilitas tempat rekreasi Taman Margasatwa Mangkang, Tinjomoyo, Taman Lele, dan Goa Kreo.

Berdasarkan data Statistik Pariwisata Provinsi Jawa Tengah, jumlah pengunjung wisata Kampung Wisata Taman Lele sebanyak 18.385 orang, Goa Kreo sebanyak 34.043 orang, Taman Margasatwa Mangkang sebanyak 227.645 orang, dan Hutan Wisata Tinjomoyo sebanyak 724 orang. Rata-rata pengeluaran retribusi tempat wisata per pengunjung Kampung Wisata Taman Lele sebesar Rp 6.250,00, Goa Kreo sebesar Rp 4.250,00, Taman Margasatwa Mangkang sebesar Rp 17.250,00, dan Hutan Wisata Tinjomoyo sebesar Rp 3.750,00. Sedangkan berdasarkan data pengunjung dan rata-rata pengeluaran retribusi tempat wisata per Pengunjung, maka dapat diperoleh hasil perhitungan total potensi retribusi tempat wisata sebesar Rp 4.189.180.250,00 dengan perincian seperti pada Tabel 4.

Tabel 4. Hasil perhitungan total potensi retribusi tempat wisata

\begin{tabular}{|l|r|r|r|}
\hline \multicolumn{1}{|c|}{$\begin{array}{c}\text { Nama obyek } \\
\text { wisata }\end{array}$} & \multicolumn{1}{|c|}{$\begin{array}{c}\text { Jumlah } \\
\text { pengunjung } \\
\text { wisata }\end{array}$} & $\begin{array}{c}\text { Rata-rata pengeluaran retribusi } \\
\text { tempat wisata per pengunjung }\end{array}$ & $\begin{array}{c}\text { Potensi retribusi } \\
\text { tempat wisata }\end{array}$ \\
\hline $\begin{array}{l}\text { Kampung Wisata } \\
\text { Taman Lele }\end{array}$ & 18.385 & 6.250 & 114.906 .250 \\
\hline Goa Kreo & 34.043 & 4.250 & 144.682 .750 \\
\hline $\begin{array}{l}\text { Taman Margasatwa } \\
\text { Mangkang }\end{array}$ & 227.645 & 17.250 & 3.926 .876 .250 \\
\hline $\begin{array}{l}\text { Hutan Wisata } \\
\text { Tinjomoyo }\end{array}$ & 724 & 3.750 & 2.715 .000 \\
\hline
\end{tabular}

Jika dibandingkan antara realisasi kinerja pendapatan retribusi tempat rekreasi dengan potensi retribusi tempat rekreasi, dapat diketahui bahwa realisasi pendapatan retribusi tempat wisata telah mendekati potensi retribusi sebesar $94,47 \%$, seperti terlihat pada Tabel 5 .

Tabel 5. Realisasi pendapatan retribusi tempat wisata

\begin{tabular}{|c|c|c|c|c|c|}
\hline $\begin{array}{c}\text { Realisasi } \\
\mathbf{2 0 1 6}\end{array}$ & Target 2017 & $\begin{array}{c}\text { Realisasi } \\
\mathbf{2 0 1 7}\end{array}$ & $\begin{array}{c}\text { \% capaian } \\
\text { target }\end{array}$ & $\begin{array}{c}\text { Potensi } \\
\text { pajak/retribusi }\end{array}$ & $\begin{array}{c}\text { \% Realisasi } \\
\text { terhadap } \\
\text { potensi }\end{array}$ \\
\hline 3.276 .539 .000 & 5.505 .923 .750 & 3.957 .379 .250 & 71,87 & 4.189 .180 .250 & 94,47 \\
\hline
\end{tabular}

\section{KESIMPULAN}

Melalui penelitian yang sudah dilakukan, dapat diberikan kesimpulan sebagai berikut. Potensi pendapatan daerah di Kota Semarang meliputi pajak hotel, pajak restoran, dan retribusi tempat wisata/ rekreasi. Sejumlah 167 usaha akomodasi mulai dari hotel non bintang hingga bintang 5 memberikan total potensi pendapatan pajak hotel sebesar Rp 72.295.451.633,00. Jika dibandingkan antara realisasi kinerja pendapatan pajak hotel dengan potensi pajak hotel, dapat diketahui bahwa realisasi Pendapatan Pajak Hotel tahun 2017 telah mendekati potensi pajak, yaitu mencapai 99,64\% dari potensi pajak yang ada. Potensi pendapatan dari restoran yang diperoleh dari 4.352 restoran menghasilkan potensi pajak sebesar Rp 833.952.000.000,00, jika dihitung rata-rata pembelian per hari adalah Rp.35.000.-/orang. Namun, jika dibandingkan antara realisasi kinerja pendapatan pajak restoran dengan potensi pajak restoran, realisasi Pendapatan pajak restoran masih jauh dari potensi pajaknya,yaitu hanya tercapai sebesar 13,38\%. Obyek wisata Taman Lele, Goa Kreo, Taman Margasatwa Mangkang, dan Hutan Wisata Tinjomoyo secara keseluruhan memilki jumlah pengunjung 280.797 orang/unit dan memberikan potensi retribusi sebesar Rp. 
4.189.180.250,-. Jika dibandingkan antara realisasi kinerja pendapatan retribusi tempat rekreasi dengan potensi retribusi tempat rekreasi, dapat diketahui bahwa Realisasi pendapatan retribusi tempat wisata telah mendekati potensi retribusi sebesar $94,47 \%$. Sebagai upaya untuk meningkatkan pendapatan daerah sektor pariwisata maka melalui sosialisasi secara berkesinambungan dan terus-menerus mengenai obyek pajak, meningkatkan pelayanan kepada wajib pajak, mengembangkan sistem reward dan punishment bagi wajib pajak yang taat pajak dan yang menunggak, mengembangkan sektor pariwisata melalui promosi maupun peningkatan kualitas pariwisata sehingga akan lebih banyak lagi wisatawan yang berkunjung.

\section{UCAPAN TERIMA KASIH}

Penulis mengucapkan terima kasih kepada Dinas pajak Semarang yang membantu memberikan data-data yang diperlukan dalam penelitian ini. Ucapan terima kasih juga ditujukan kepada Rektor Universitas 17 Agustus 1945 yang telah memberikan ijin kepada peneliti melakukan penelitian sampai selesai.

\section{DAFTAR PUSTAKA}

Amalia, U. T., \& Purwaningsih, E. (2016). Local Wisdom Tourism Development of Semarang With Tourism Cluster System As an Action for Sustainble Economics Development. Proceedings of Education and Language International Conference, I(1), 871-879.

Denny Cessario Sutrisno. (2013). Pengaruh Jumlah Obyek Wisata, Jumlah Hotel, Dan Pdrb Terhadap Retribusi Pariwisata Kabupaten / Kota Di Jawa Tengah. Economics Development Analysis Journal 2 (4) pp 435-445

Devy and R. B. Soemanto. (2017).Pengembangan Obyek Dan Daya Tarik Wisata Alam Sebagai Daerah Tujuan Wisata Di Kabupaten Karanganyar,” Jurnal Sosiol DILEMA, vol. 32, no. 1, pp. 34-44..

D. D. Wahjudi. (2014).Kontribusi Pajak Daerah dan Retribusi Daerah Terhadap Pendapatan Asli Daerah dan Anggaran Pendapatan dan Belanja Daerah guna Mendukung Pelaksanaan Otonomi Daerah (Studi Komparasi Pemerintah Kota Semarang dan Surakarta), Jurnal Bisnis dan Ekonomi, vol. 21, no. 2, pp. 189-205, 2014.

Kadarwati, A. (2008). Potensi dan Pengembangan Obyek Wisata Kota Lama Semarang Sebagai Daya Tarik Wisata diSemarang, Laporan Tugas Akhir, Program Diploma III, Jurusan Usaha Perjalanan Wisata, Fakultas Sastra dan Seni Rupa, Universitas Sebelas Maret Surakarta.

Kurniawan. (2017). Dampak Sosial Ekonomi Pembangunan Pariwisata Umbul Sidomukti Kecamatan Bandungan Kabupaten Semarang, Economic Development Analysis Journal, vol. 4, no. 4, pp. 443451.

Mardiyani Yuyun. (2015). Pengaruh Fasilitas Dan Promosi Terhadap Kepuasan Pengunjung Melalui Keputusan Berkunjung Sebagai Variabel Intervening Pada Objek Wisata Kota Semarang, Managemen Analisis jurnal. vol. 4, no. 1, pp. 65-75, 2015.

Masrofi. (2004). Potensi dan Analisis Faktor-Faktor yang Mempengaruhi Penerimaan Pajak Daerah dan Retribusi Daerah (Studi Kasus di Kota Semarang).Masters thesis, Program Pasca Sarjana Universitas Diponegoro.

Mayang Vini Setya. (2017). Strategi Dinas Kebudayaan dan Pariwisata Kota Semarang Dalam Upaya Mengembangkan Pariwisata Kota Semarang, Journal of Politic and Government Studies. vol. 6, no. 4, pp. 401-410, 2017.

Qadarrochman. (2010). Analisis Penerimaan Daerah Dari Sektor Pariwisata Di Kota Semarang Dan Faktor-Faktor Yang Mempengaruhinya,” Skripsi, p. 119.

Rizal Abu. (2016). Analisis Penerimaan Daerah dari Sektor Pariwisata Kota Surabaya Tahun 2010-2014, Jurnal Ekonomi dan Bisnis, vol. 2, pp. 147-166. 
Jurnal Ekonomi \& Ekonomi Syariah Vol 4 No 2, Juni 2021

E-ISSN : 2599-3410 | P-ISSN : 2614-3259

DOI : https://doi.org/10.36778/jesya.v4i2.380

Saputro. (2015). Analisis Penerimaan Daerah Sektor Pariwisata Sekabupaten/Kota di Jawa Tengah dan Faktor-Faktor yang mempengaruhinya. Skripsi Fakultas Ekonomika dan Bisnis universitas Diponegoro.

Sutrisno, D.C. (2013). Pengaruh Jumlah Obyek Wisata, Jumlah Hotel, dan PDRB Terhadap Retribusi Pariwisata Kabuupaten/Kota di Jawa Tengah. Economics Development Analysis Journal, 2 (4). Diakses pada tanggal 22 November 2020 dari http://journal.unnes.ac.id/sju/index.php/edaj.

Suwena and I. G. N. Widyatmaja. (2017). Pengetahuan Dasar Ilmu Pariwisata, Denpasar, Pustaka Larasan. 